\title{
Rapid reorganization in ocean biogeochemistry off Peru towards the end of the Little Ice Age
}

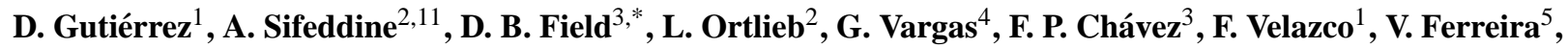 \\ P. Tapia ${ }^{6}$, R. Salvatteci ${ }^{1,5}$, H. Boucher ${ }^{2}$, M. C. Morales $^{7}$, J. Valdés ${ }^{8}$, J.-L. Reyss ${ }^{9}$, A. Campusano ${ }^{1}$, M. Boussafir ${ }^{10}$, \\ M. Mandeng-Yogo ${ }^{2}$, M. García ${ }^{2}$, and T. Baumgartner ${ }^{5}$ \\ ${ }^{1}$ Instituto del Mar del Perú (IMARPE), Dirección de Investigaciones Oceanográficas, Av. Gamarra y Gral. Valle, \\ $\mathrm{s} / \mathrm{n}$, Chucuito, Callao, Peru \\ ${ }^{2}$ Institut de Recherche pour le Développement (IRD), UR Paléotropique (presently: LOCEAN, UMR 7159 CNRS-IRD-Univ. \\ P. \& M. Curie-MNHN), 32 Avenue Henri Varagnat, 93143 Bondy cedex, France \\ ${ }^{3}$ Monterey Bay Aquarium Research Institute, 7700 Sandholdt Road, Moss Landing, CA 95039, USA \\ ${ }^{4}$ Departamento de Geología, Facultad de Ciencias Físicas y Matemáticas, Universidad de Chile, Plaza Ercilla 803, \\ Santiago, Chile \\ ${ }^{5}$ Centro de Investigación Científica y de Educación Superior de Ensenada (CICESE), Km. 107 Carretera Tijuana - Ensenada, \\ Ensenada, 22860, Mexico \\ ${ }^{6}$ Biological Sciences Department, Universidad Peruana Cayetano Heredia, Av. Honorio Delgado 430, Lima 31, Peru \\ ${ }^{7}$ Laboratorio de Paleontología, Instituto Geológico Minero Metalúrgico, Av. Canadá 1470, Lima 41, Peru \\ ${ }^{8}$ Facultad de Recursos del Mar, Universidad de Antofagasta, Casilla 170, Antofagasta, Chile \\ ${ }^{9}$ Laboratoire des Sciences de Climat et de l'Environnement, UMR CEA - CNRS-Univ. Versailles-Saint Quentin en Yveline, \\ 91198 Gif-Sur-Yvette, France \\ ${ }^{10}$ Institut des Sciences de la Terre (ISTO), Université d'Orléans, 45067 Orléans, France \\ ${ }^{11}$ Departamento de Geoquimica, Universidade Federal Fluminense, Niteroi-RJ, Brasil \\ *now at: Hawaii Pacific University, College of Natural Sciences, 45-045 Kamehameha Highway, Kaneohe, \\ HI, 96744-5297, USA
}

Received: 21 August 2008 - Published in Biogeosciences Discuss.: 29 September 2008

Revised: 5 May 2009 - Accepted: 5 May 2009 - Published: 15 May 2009

\begin{abstract}
Climate and ocean ecosystem variability has been well recognized during the twentieth century but it is unclear if modern ocean biogeochemistry is susceptible to the large, abrupt shifts that characterized the Late Quaternary. Time series from marine sediments off Peru show an abrupt centennial-scale biogeochemical regime shift in the early nineteenth century, of much greater magnitude and duration than present day multi-decadal variability. A rapid expansion of the subsurface nutrient-rich, oxygen-depleted waters resulted in the present-day higher biological productivity, including pelagic fish. The shift was likely driven by a northward migration of the Intertropical Convergence Zone and the South Pacific Subtropical High to their present day locations, coupled with a strengthening of Walker circulation, towards the end of the Little Ice Age. These findings reveal the
\end{abstract}

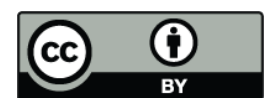

Correspondence to: D. Gutiérrez (dgutierrez@imarpe.gob.pe) potential for large reorganizations in tropical Pacific climate with immediate effects on ocean biogeochemical cycling and ecosystem structure.

\section{Introduction}

Paleoclimate evidence for large, rapid shifts in climate and biogeochemistry associated with Dansgaard-Oeschger events during the last glacial period indicate that the oceanatmosphere climate system was susceptible to rapid changes in circulation and biogeochemical cycling (Schmittner et al., 2007). The Holocene appears more stable, however, large changes in tropical rainfall patterns at the Holocene thermal maximum (Haug et al., 2001), during the Medieval Climatic Anomaly (MCA) and the Little Ice Age (LIA) have been documented (Graham et al., 2007; Rein et al, 2004; Haug et al., 2001; Newton et al., 2006).

Published by Copernicus Publications on behalf of the European Geosciences Union. 

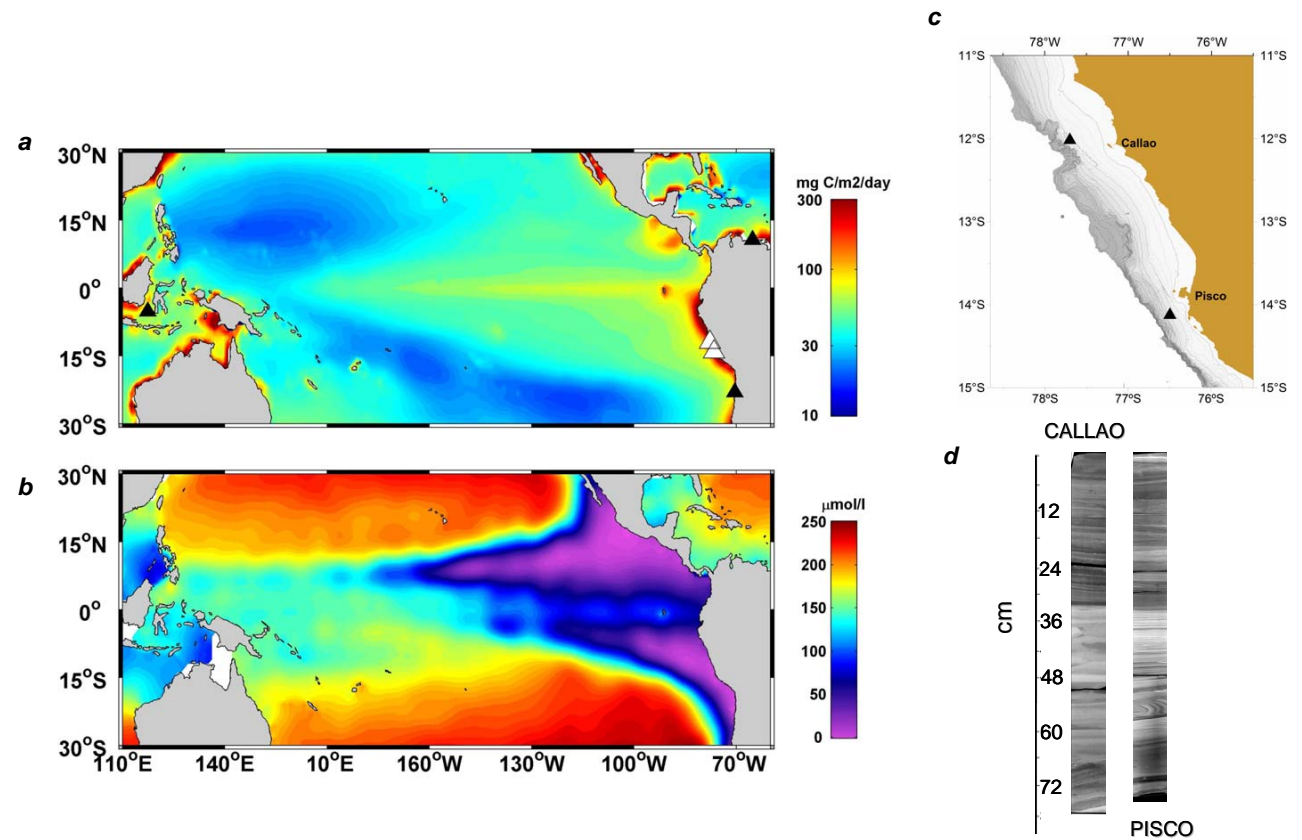

Fig. 1. (a) Map of average POC flux $\left(\mathrm{g} \mathrm{C} \mathrm{m}^{-2} \mathrm{y}^{-1}\right)$ from the euphotic zone for 1999-2006 estimated from satellite measurements of chlorophyll and temperature in the Tropical Pacific (Laws et al., 2000). The highest present day export rates currently occur off the coast of Peru; (b) Present day climatolological map of dissolved oxygen at $150 \mathrm{~m}$ depth $\left(\mu \mathrm{mol} \mathrm{L}^{-1}\right)$, from the World Ocean Data Center, showing the persistently low oxygen in the Eastern Tropical Pacific. The locations of the paleorecords used in this study are shown as white triangles; other paleorecord sites discussed in the text (Cariaco Basin, Caribbean Sea; Mejillones Bay, Northern Chile; and Makassar Strait, Indo Pacific) are shown as black triangles; (c) Zoom of the shelf off Central Peru, showing the position of the boxcores off Callao and Pisco (black triangles). Bathymetric contour lines are shown for each $100 \mathrm{~m}$ depth (thick) and each $25 \mathrm{~m}$ depth (thin); (d) X-ray digital radiographies for both box cores.

The LIA was associated with lower solar radiation and enhanced volcanic activity, resulting in large expansions of mountain glaciers in Europe and North America during the fifteenth to nineteenth centuries (Cronin et al., 2002; Broecker et al., 2000), and by drier conditions in the Northern Tropics (Haug et al., 2001). During the LIA, stronger northern trades may have resulted from enhanced latitudinal temperature gradients under the cooler Northern Hemisphere conditions, displacing southward the mean ITCZ position and its associated precipitation belt (Koutavas and Lynch-Stieglitz, 2004). Alternatively, large-scale cooling by solar and/or volcanic activity could have reduced the zonal temperature gradient in the Equatorial Pacific, again driving the marine ITCZ southward, particularly in the Eastern Pacific (Peterson and Haug, 2006; Mann et al., 2005).

Seasonal and interannual changes of the ITCZ and the trade winds are the main sources of biogeochemical variability in the Eastern Tropical South Pacific (ETSP), modulating biological productivity and oxygen concentrations (Barber and Chávez, 1983; Pennington et al., 2006). Here we examine the relationships between biogeochemical cycles and centennial-scale climate modes during the past $\sim 700$ years in the ETSP, and focus particularly on the transition between the LIA and the modern warmer climate. Given evidence for ecosystem changes associated with current warming trends (Field et al., 2006), the potential for crossing attractor thresholds or "tipping points" and undergoing large regime shifts (Mantua, 2004) is of major interest, particularly in regions that are heavily dependent on living marine resources.

We develop time series of multiple proxies from cores collected in the laminated sediments of the upper Peruvian margin to reconstruct the paleoceanographic and paleoecological conditions. High resolution sedimentary paleo-archives are preserved in certain topographic areas of the Peruvian margin within the oxygen minimum zone (OMZ) (Fig. 1; Reinhardt et al., 2003). The sediment cores were retrieved from mud lenses off Callao ( $12^{\circ} \mathrm{S}, 184 \mathrm{~m}$, Krissek et al., 1980) and off Pisco (14 S, 300 m, Gutiérrez et al., 2006).

\section{Materials and methods}

The Callao $\left(\sim 12^{\circ} \mathrm{S}\right)$ and Pisco $\left(\sim 14^{\circ} \mathrm{S}\right)$ areas were selected as sites for box coring based on previous sedimentological and geochemical information from exploratory surveys and the literature. Two Soutar-box cores were collected: one from the shelf off Callao (B0405-13, $12^{\circ} 00^{\prime} \mathrm{S}, 72^{\circ} 42^{\prime} \mathrm{S}$, $184 \mathrm{~m}$ ) and the other one from the upper slope off Pisco (B0405-06, $\left.14^{\circ} 07^{\prime} \mathrm{S}, 76^{\circ} 30^{\prime} \mathrm{S}, 299 \mathrm{~m}\right)$ from the R/V José 
Olaya Balandra (IMARPE) in May 2004 (Fig. 1). Subsampling for proxy determinations was performed following the stratigraphy, i.e. according to the geometry of couplets of laminae or bands (Gutiérrez et al., 2006; Morales et al., 2007).

The quantitative mineralogical composition, including lithic and biogenic-derived compounds, was obtained by Fourier Transformed Infrared Spectrometry (FTIR) (Bertaux et al., 1998). More detailed explanations on FTIR methodology are given in Sifeddine et al. (2008). Total organic carbon was determined from total carbon measurements with a Thermo Electron CNS elemental analyzer, corrected for carbonate content. $\delta^{15} \mathrm{~N}$ was determined by mass spectrometry after acidification at the Department of Geosciences, University of Arizona (USA). Analyses of Molybdenum (Mo) and Cadmium (Cd) were carried out by ICP-MS and ICP-AES (Ultramass Varian), respectively, after hot plate acid digestion (combination of acid $\mathrm{HF}, \mathrm{HNO}_{3}$ and $\mathrm{HClO}_{4}$ ), which was used to eliminate organic matter and to remove silicates (Cho et al., 1999).

Subsamples for foraminifera and fish scales were heated with hydrogen peroxide and sodium pyrophosphate to remove the organic matter and then were sieved through a $125 \mu \mathrm{m}$ mesh and $355 \mu \mathrm{m}$ mesh. The retained material in the $355 \mu \mathrm{m}$ mesh was sorted for fish remains (bones and scales) while foraminifers were counted and identified from the smaller size fraction with stereo-microscopy. Diatom valves and other siliceous remains were determined from splits that were acid cleaned with $\mathrm{HCl} 10 \%$ and $\mathrm{H}_{2} \mathrm{O}_{2} 30 \%$ (Batterbee, 1989). Quantitative slides were made using $100 \mu \mathrm{L}$ of acid-clean residue of about $0.1 \mathrm{~g}$ of wet-sediment (equivalent of $0.02-0.03 \mathrm{~g}$ of dry-sediment) diluted on a $20-\mathrm{mL}$ vial. A $22 \times 22 \mathrm{~mm}$ coverslip was permanently fixed over a $1^{\prime \prime} \times 3^{\prime \prime}$ glass slide with Zrax ${ }^{\circledR}$ (R.I.=1.74) to enhance diatom taxonomic features. Identifications were done with contrastphase microscopy techniques.

Mass accumulation rates (MAR) for the past $\sim 135$ years were determined from downcore profiles of ${ }^{241} \mathrm{Am}$ and excess ${ }^{210} \mathrm{~Pb}$. Radiocarbon ages from bulk organic sedimentary carbon were used to solve the geochronology for the whole record (see supplementary information: http://www.biogeosciences.net/6/835/2009/ bg-6-835-2009-supplement.pdf). It has been suggested that ${ }^{14} \mathrm{C}$ dating of bulk organic carbon provides reliable results for the Peruvian margin sediments, by comparison of dated bulk organic matter and alkenone ${ }^{14} \mathrm{C}$ dates (Higginson and Altabet, 2004). In this study, geochemical and petrographic inspection of the samples ensured that the dated organic matter in the age model was dominated by homogenous and granular amorphous organic matter, which is associated with high productivity linked to upwelling (Boussafir et al., 1995; Pichevin et al., 2004; Valdés et al., 2004). This was done to minimize possible bias of the age models in the older part of the cores due to the presence of reworked material in the samples.
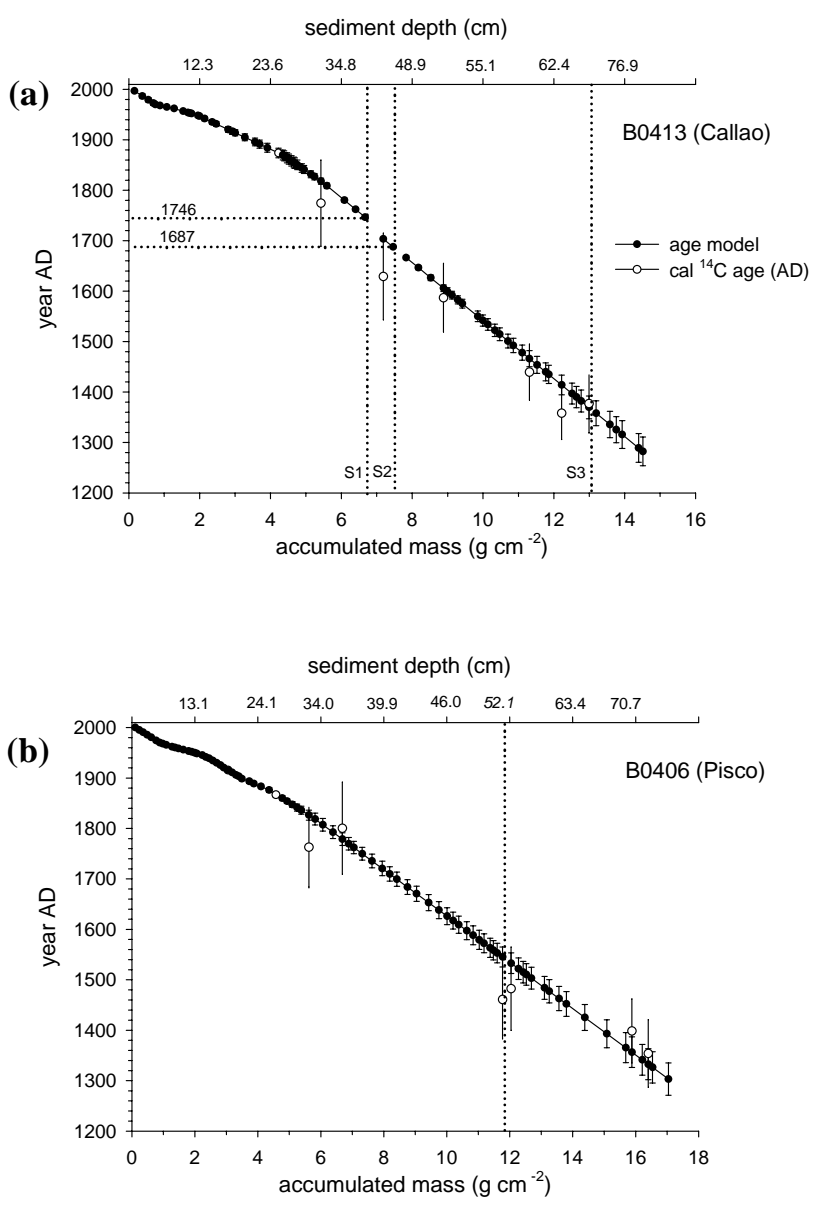

Fig. 2. (a) Age model (accumulated mass versus age) for the Callao core. The predicted dates are compared with the calibrated radiocarbon ages, using the estimated local reservoir age $(\Delta R)$. The reference sediment depths are depicted in the top axis. Shortdashed lines indicate the slumps positions. The mid-section slumps $(\mathrm{S} 1, \mathrm{~S} 2)$ are interpreted as markers of the $1687 \mathrm{AD}$ and $1746 \mathrm{AD}$ earthquakes (Dorbath et al., 1990). (b) Age model (accumulated mass versus age) for the Pisco core. The predicted dates are compared with the calibrated radiocarbon ages, using the estimated $\Delta R$. The slump at about $52 \mathrm{~cm}$ sediment depth is indicated with a short-dashed line. For more information, look at the supplementary information: http://www.biogeosciences.net/6/835/2009/ bg-6-835-2009-supplement.pdf.

The conventional radiocarbon ages were calibrated taking into account global and local reservoir effects that were estimated (supplementary information: http://www.biogeosciences.net/6/835/2009/ bg-6-835-2009-supplement.pdf). A linear regression between these calibrated ${ }^{14} \mathrm{C}$ ages and accumulated mass was then used to estimate MAR for the lower section of the cores. The final age models combined the ${ }^{210} \mathrm{~Pb}$-based chronology with the above mentioned age-mass regression fit, and also took into account stratigraphic features (Fig. 2). 


\section{Results and discussion}

\subsection{Lithology and geochronology}

The Pisco and Callao cores show an almost identical shift in core lithologies at about $35 \mathrm{~cm}$ (Fig. 3a, j), as observed in dry bulk density and X-ray grey level, despite differences in location (300 km of distance) and depth within the OMZ. There is a striking similarity in the core lithologies and downcore patterns of lithic, geochemical and biogenic proxies between the two sites (Fig. 3), which indicates that regionalto large-scale processes largely determine the temporal variations. Terrigenous sedimentation dominates below $35 \mathrm{~cm}$, whereas diatom/siliceous and organic matter are major constituents above that depth.

The MAR varied by a factor of two, with the highest average values after ca. 1950 AD in both cores (Callao: $0.034 \pm 0.001 \mathrm{~g} \mathrm{~cm}^{-2} \mathrm{y}^{-1}$; Pisco: $0.036 \pm 0.001 \mathrm{~g} \mathrm{~cm}^{-2} \mathrm{y}^{-1}$ ) and lowest values before ca. 1820 AD (Callao: $0.017 \pm 0.001 \mathrm{~g} \mathrm{~cm}^{-2} \mathrm{y}^{-1}$; Pisco: $0.022 \pm 0.001 \mathrm{~g} \mathrm{~cm}^{-2} \mathrm{y}^{-1}$ ) (Table 1). The cores spanned the last $700 \pm 30$ years approximately. Dating and sampling resolution resolve variability at sub-decadal to inter-decadal time-scales (Fig. 2; see also supplementary material: http://www.biogeosciences.net/6/ 835/2009/bg-6-835-2009-supplement.pdf). The shift in core lithologies is dated near $1820 \mathrm{AD}$ (Fig. 3b, k).

The period since the late nineteenth century to the present show sedimentation rates of $1.8-2.1 \mathrm{~mm} \mathrm{y}^{-1}$ for Callao, and 1.9-2.3 $\mathrm{mm} \mathrm{y}^{-1}$ for Pisco, very similar to those of Koide and Goldberg (1982) and to Rein et al. (2004), who studied cores near our study sites using ${ }^{210} \mathrm{~Pb}$ or ${ }^{137} \mathrm{Cs}$ (Table 1). For the period before the late nineteenth century our sedimentation rates $\left(0.6-0.7 \mathrm{~mm} \mathrm{y}^{-1}\right)$ are similar to previous studies based on ${ }^{14} \mathrm{C}$ measurements in the sedimentary organic fraction (Rein et al., 2004; Agnihotri et al., 2006; Skilbeck and Fink, 2006), even though there are differences in local reservoir ages used.

\subsection{Multidecadal to centennial variability in multiple proxies}

The multiple geochemical and biogenic proxies developed in the study are used to reconstruct past changes of water column oxygenation, sediment redox conditions and productivity, according to their source and downcore behaviour (Fig. 3b, k). In order to constrain the interpretation of our records, we compare our results with some records developed by Sifeddine et al. (2008) as Total Organic Carbon (TOC), Molybdenum (Mo) and Lithogenic input. The variation pattern of fluxes of these proxies is also evident with concentrations, indicating that flux variability represents true changes in the input and not only changes in sedimentation rate (Sifeddine et al., 2008). The same applies for the multiple proxies introduced here. Nevertheless, we preferred to use fluxes instead of concentrations in order to control dilution effects in the sedimentary matrix.

For both cores several of the proxies show slightly higher levels before ca. $1400 \mathrm{AD}$, followed by low values until $1820 \mathrm{AD}$, when most of the geochemical and biogenic proxies exhibit a rapid change towards higher values, within one to two decades given chronological errors. A sudden decrease of lithic fluxes occurred also around $1820 \mathrm{AD}$, suggesting that the western flank of the Peruvian Andes shifted from a wetter to a drier condition at this time (Sifeddine et al., 2008).

\subsubsection{Water column biogeochemistry}

$\delta^{15} \mathrm{~N}$ of organic matter exhibited remarkably similar levels between sites at the different centennial periods (Fig. 3c, 1). Values from 1400 to $1820 \mathrm{AD}(4.8 \pm 0.6 \%$ ), corresponding to the LIA, were about $1 \%$ o lighter than before $1400 \mathrm{AD}$. The LIA period bears multidecadal variability; timing of periods with lighter $\delta^{15} \mathrm{~N}$ values at both sites were about 1480 $1530 \mathrm{AD}$, the mid seventeenth century and 1780-1810 AD. Around $1820 \mathrm{AD}$ a rapid change towards heavier values occurred at both sites within one or two decades. $\delta^{15} \mathrm{~N}$ reached an average of $6.7 \pm 0.6 \%$ o for the third period, about $2 \%$ o heavier than the preceding centuries.

The $\delta^{15} \mathrm{~N}$ from our records agrees with the $\delta^{15} \mathrm{~N}$ reported by Agnihotri et al. (2008) in a 2300-year late Holocene sedimentary record at $11^{\circ} \mathrm{S}$ off Peru. However, different chronological approaches preclude a direct comparison between our 700-year record and the $11^{\circ} \mathrm{S}$ record reported by Agnihotri et al. (2008). These authors employed an overall reservoir age correction of $420 \pm 170$ years, implying a local reservoir effect $(\Delta R)$ from negligible levels to ca. 170 years, while in this study, the $\Delta R$ was estimated to be $188 \pm 79$ years for Pisco and $279 \pm 53$ years for Callao, consistent with previous estimates reported in the literature (Taylor and Berger, 1967; Jones et al., 2007, see also supplementary information: http://www.biogeosciences.net/6/835/ 2009/bg-6-835-2009-supplement.pdf).

Downcore variations of $\delta^{15} \mathrm{~N}$ can reflect changes in organic matter source, in diagenesis or in the $\delta^{15} \mathrm{~N}$ of the nitrate taken up by phytoplankton (Altabet et al., 1999; Martínez et al., 2006, DePol-Holz et al., 2007). Analysis of the organic fraction (palynofacies) indicates that over $95 \%$ of the organic matter is marine in the Callao core, and over $90 \%$ is marine in most of the Pisco core (Suppl. Fig. SF2, see http://www.biogeosciences.net/6/835/ 2009/bg-6-835-2009-supplement.pdf). Terrestrial plant organic matter is typically high $(>20)$ in $\mathrm{C}: \mathrm{N}$ ratios and light in $\delta^{15} \mathrm{~N}$ (Meyers, 1997). Our downcore C:N records were closer to the marine Redfield ratio and did not show any significant change around 1820 AD. Downcore C:N was $10.2 \pm 0.7$ in Callao, whereas in Pisco it was higher before $1600 \mathrm{AD}(10.9 \pm 0.5)$ than after this date $(8.9 \pm 0.8)$. The $\mathrm{C}: \mathrm{N}$ ratio confirms that there were no significant changes in the 
Table 1. Mean sedimentation rates (SR) in the central Peruvian upper margin. Results of this study (including MAR) and of previous studies are compared.

\begin{tabular}{|c|c|c|c|c|c|c|c|}
\hline core & latitude (S) & $\begin{array}{l}\text { water depth } \\
(\mathrm{m})\end{array}$ & $\begin{array}{c}\text { MAR } \\
\left(\mathrm{g} \mathrm{cm}^{-2} \mathrm{y}^{-1}\right)\end{array}$ & $\begin{array}{c}\text { mean SR } \\
\mathrm{mm} \mathrm{y}^{-1}\end{array}$ & $\begin{array}{l}\text { time window } \\
\text { (year } A D \text { ) }\end{array}$ & dating method & Source \\
\hline 1228 & $11^{\circ} 04^{\prime}$ & 252 & & $\begin{array}{l}0.4 \\
0.7\end{array}$ & $\begin{array}{c}1430-1950 A D \\
<0-1430 A D\end{array}$ & $\begin{array}{l}{ }^{14} \mathrm{C}(\mathrm{n}=1) \\
{ }^{14} \mathrm{C}(\mathrm{n}=6)\end{array}$ & $\begin{array}{l}\text { Skilbeck \& Fink (2006) } \\
\text { Skilbeck \& Fink (2006) }\end{array}$ \\
\hline 1229 & $10^{\circ} 59^{\prime}$ & 151 & & $\begin{array}{l}0.3 \\
1.0\end{array}$ & $\begin{array}{c}1300-1950 A D \\
<0-1300 A D\end{array}$ & $\begin{array}{l}{ }^{14} \mathrm{C}(\mathrm{n}=1) \\
{ }^{14} \mathrm{C}(\mathrm{n}=6)\end{array}$ & $\begin{array}{l}\text { Skilbeck \& Fink (2006) } \\
\text { Skilbeck \& Fink (2006) }\end{array}$ \\
\hline W7706-40 & $11^{\circ} 18^{\prime}$ & 186 & & 0.7 & $<0-1650$ & ${ }^{14} \mathrm{C}(\mathrm{n}=6)$ & Agnihotri et al. (2008) \\
\hline B0413 & $12^{\circ} 00^{\prime}$ & 184 & $\begin{array}{l}0.034 \pm 0.001 \\
0.031 \pm 0.003 \\
0.021 \pm 0.005 \\
0.017 \pm 0.001\end{array}$ & $\begin{array}{l}2.1 \\
1.8 \\
1.5 \\
0.6\end{array}$ & $\begin{array}{c}>1952 \text { AD } \\
1870-1952 A D \\
1818-1870 A D \\
\text { ca.1300-1818 AD }\end{array}$ & $\begin{array}{c}{ }^{241} \mathrm{Am} \\
{ }^{210} \mathrm{~Pb}-\mathrm{CFCS} \\
{ }^{14} \mathrm{C} /{ }^{210} \mathrm{~Pb} \\
{ }^{14} \mathrm{C}(\mathrm{n}=6) \text {, stratigraphy }\end{array}$ & $\begin{array}{l}\text { This study } \\
\text { This study } \\
\text { This study } \\
\text { This study }\end{array}$ \\
\hline 2312 & $12^{\circ} 02^{\prime}$ & 194 & & $\begin{array}{l}3.3 \\
1.5\end{array}$ & $\begin{array}{l}1946-1974 \\
1870-1946\end{array}$ & $\begin{array}{l}{ }^{210} \mathrm{~Pb}-\mathrm{CFCS} \\
{ }^{210} \mathrm{~Pb}-\mathrm{CFCS}\end{array}$ & $\begin{array}{l}\text { Koide \& Goldberg (1982) } \\
\text { Koide \& Goldberg (1982) }\end{array}$ \\
\hline $106 \mathrm{KL}$ & $12^{\circ} 03^{\prime}$ & 184 & & $\begin{array}{l}1.3 \\
0.9\end{array}$ & $\begin{array}{c}1900-1960 ? \\
\text { ca. } 1400-1900\end{array}$ & $\begin{array}{l}{ }^{210} \mathrm{~Pb},{ }^{137} \mathrm{Cs} \\
{ }^{14} \mathrm{C}(\mathrm{n}=2)\end{array}$ & $\begin{array}{l}\text { Rein et al. (2004) } \\
\text { Rein et al. (2004) }\end{array}$ \\
\hline B0406 & $14^{\circ} 07^{\prime}$ & 299 & $\begin{array}{l}0.036 \pm 0.001 \\
0.033 \pm 0.009 \\
0.025 \pm 0.006 \\
0.022 \pm 0.001\end{array}$ & $\begin{array}{l}2.3 \\
1.9 \\
1.3 \\
0.7\end{array}$ & $\begin{array}{c}>1952 \text { AD } \\
1860-1952 A D \\
1818-1860 A D \\
\text { ca. } 1300-1818 \text { AD }\end{array}$ & $\begin{array}{l}{ }^{241} \mathrm{Am} \\
{ }^{210} \mathrm{~Pb}-\mathrm{CRS} \\
{ }^{14} \mathrm{C} /{ }^{210} \mathrm{~Pb} \\
{ }^{14} \mathrm{C}(\mathrm{n}=6)\end{array}$ & $\begin{array}{l}\text { This study } \\
\text { This study } \\
\text { This study } \\
\text { This study }\end{array}$ \\
\hline 1909 & $14^{\circ} 39^{\prime}$ & 183 & & $\begin{array}{l}3.2 \\
1.5\end{array}$ & $\begin{array}{l}1946-1974 \\
1870-1946\end{array}$ & $\begin{array}{l}{ }^{210} \mathrm{~Pb}-\mathrm{CFCS} \\
{ }^{210} \mathrm{~Pb}-\mathrm{CFCS}\end{array}$ & $\begin{array}{l}\text { Koide \& Goldberg (1982) } \\
\text { Koide \& Goldberg (1982) }\end{array}$ \\
\hline
\end{tabular}

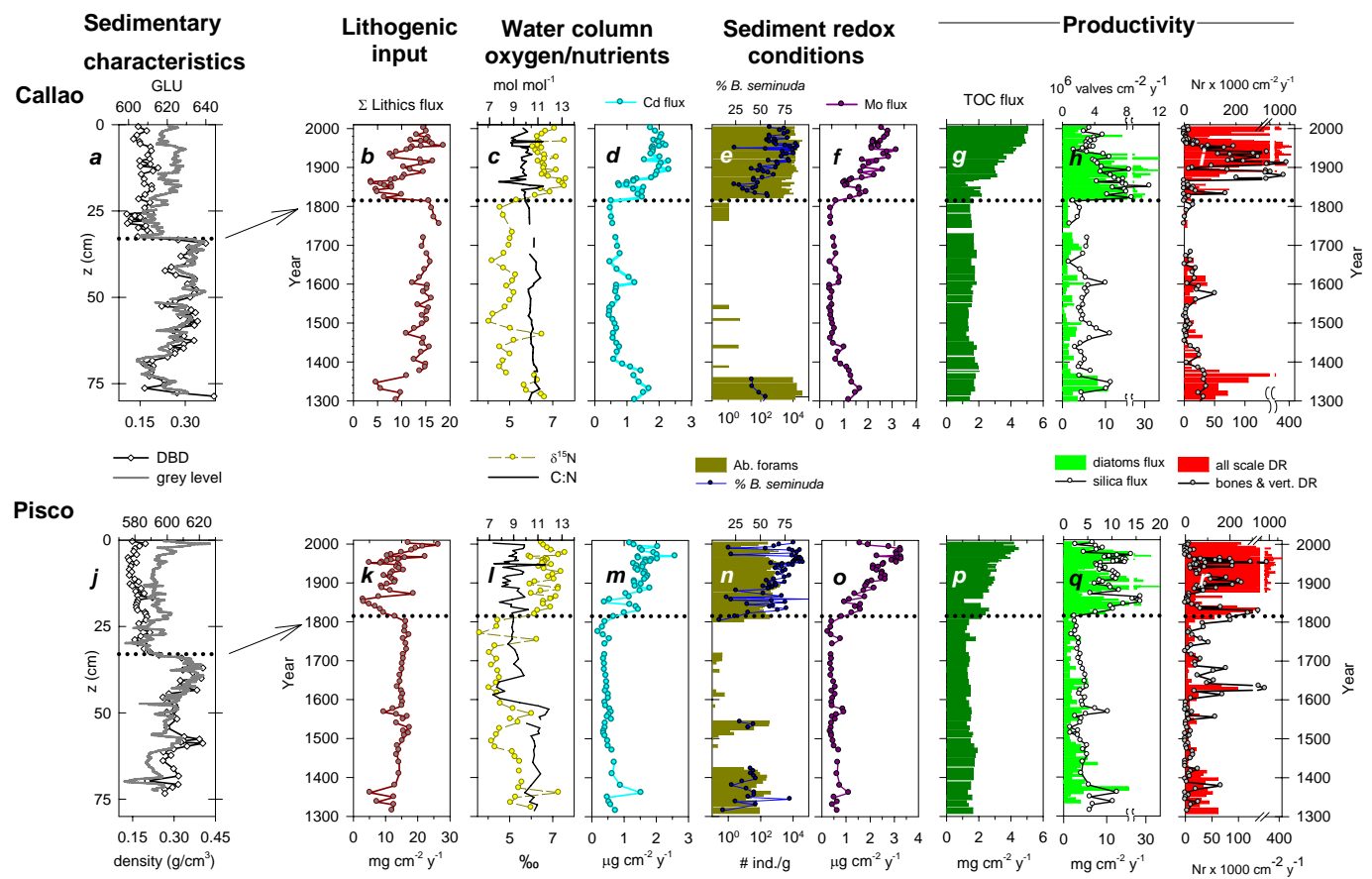

Fig. 3. Multiple proxies developed in the cores collected off Callao (upper panels; a-i) and off Pisco (lower panels; j-r). (a, j) Dry bulk density (white circles; $\mathrm{g} \mathrm{cm}^{-3}$ ) and X-radiography gray level units (gray lines) are shown as a function of depth. All other proxies are shown as a function of time: (b, k) Flux of the sum of lithic components (feldspar, quartz and clays; Sifeddine et al., 2008); (c, 1) yellow circles: $\delta^{15} \mathrm{~N}$ values of sedimentary organic matter (\%o), line: C:N molar ratios; $(\mathrm{d}, \mathrm{m})$ flux of elemental Cadmium $\left(\mu \mathrm{g} \mathrm{cm}^{-2} \mathrm{y}^{-1}\right) ;(\mathrm{e}, \mathrm{n})$ bars: total foraminiferal abundance ( $\mathrm{Nr}$ ind. $\mathrm{g}^{-1}$ ), blue circles: percent of Bolivina seminuda in the benthic foraminiferal assemblage; (f, o) flux of elemental Molybdenum $\left(\mu \mathrm{g} \mathrm{cm}^{-2} \mathrm{y}^{-1}\right)$ reported by Sifeddine et al. (2008); (g, p) flux of total organic carbon ( $\left.\mathrm{mg} \mathrm{C} \mathrm{cm}^{-2} \mathrm{y}^{-1}\right)($ Sifeddine et al., 2008); (h, q) bars: diatom accumulation rate $\left(10^{6}\right.$ valves $\left.\mathrm{cm}^{-2} \mathrm{y}^{-1}\right)$, white circles: flux of biogenic silica $\left(\mathrm{mg} \mathrm{cm}^{-2} \mathrm{y}^{-1}\right)$; (i, r) bars: fish scale deposition rates $\left(\mathrm{Nr} \times 1000 \mathrm{~cm}^{-2} \mathrm{y}^{-1}\right)$, gray circles: deposition rates of fish bones and vertebrae $\left(\mathrm{Nr} \times 1000 \mathrm{~cm}^{-2} \mathrm{y}^{-1}\right)$. A shift in DBD and grey level at $35 \mathrm{~cm}$ depth and its corresponding date $(1820 \mathrm{AD})$ is indicated in each panel by dotted lines and connected with an arrow. 
source of organic matter, and it also rules out the possibility that diagenesis was the controlling factor for $\delta^{15} \mathrm{~N}$, since downcore varations of $\delta^{15} \mathrm{~N}$ and $\mathrm{C}: \mathrm{N}$ ratios were independent. The stable C:N ratios indicate that there was not a preferential removal of more labile $\mathrm{N}$-rich organic compounds during prolonged periods with low $\delta^{15} \mathrm{~N}$; increasing C:N ratios would be associated with diagenesis of organic matter (Martínez et al., 2006).

In the oxygen-deficient waters of the ETSP nitrate is used as an electron donor for respiration during degradation of organic matter. Hence settling organic matter $\delta^{15} \mathrm{~N}$ will reflect ${ }^{15} \mathrm{~N}$-enriched nitrate taken up by phytoplankton from upwelled oxygen-depleted water masses (Altabet et al., 1999; De Pol et al., 2007). Therefore our $\delta^{15} \mathrm{~N}$ records ultimately reflect changes in the intensity of nitrate reduction in the source waters for primary producers, i.e. changes in water column oxygenation. The same conclusions have been reached for other sedimentary $\delta^{15} \mathrm{~N}$ records in the ETSP (DePol et al., 2007; Agnihotri et al., 2008) and this interpretation is consistent with our other proxies of oxygenation and productivity.

$\mathrm{Cd}$ exhibits nutrient-like characteristics in the water column; dissolved $\mathrm{Cd}$ is normally depleted in surface waters by phytoplankton uptake. Equatorial Subsurface Waters (ESSW), which are the main source of upwelling in the ETSP, are enriched in dissolved Cd (Valdés et al., 2006; Takesue et al., 2004). Cadmium is delivered to sediments in association with organic matter and becomes fixed in reducing sediments (Tribovillard et al., 2006; Böning et al., 2004). Cd in sediments can then be considered a proxy of paleoupwelling and paleoproductivity (Dean et al., 2006). In our records, Cd flux decreases from the fourteenth to the fifteenth century, and then remains at very low levels (Fig. 3d, m). Like $\delta^{15} \mathrm{~N}, \mathrm{Cd}$ exhibits a step-like increase in baseline values near $1820 \mathrm{AD}$, and later on, multidecadal oscillations without any particular trend. The similarity in the behaviour of $\mathrm{Cd}$ and $\delta^{15} \mathrm{~N}$ can be interpreted as a rapid change in source water properties towards a new biogeochemical regime with lower oxygen and higher nutrient concentrations. Sifeddine et al. (2008) determined that primary productivity, as inferred by Total Organic Carbon (TOC), was lower and constant before the shift (Fig. 3g, p). It increased rapidly with the shift, showing a non-linear transition until $1870 \mathrm{AD}$. Thereafter, it exhibited a significant positive trend until the present.

Thus the large shift around $1820 \mathrm{AD}$ most likely reflects a large-scale depletion in oxygen below the mixed layer and surface nutrient enrichment. The shift must have been associated with an expansion of the nutrient-rich, oxygen-poor ESSW that primarily feeds coastal upwelling in the ETSP (Strub et al., 1998). In their 2300-year record, Agnihotri et al. (2008) determined four short centennial periods of "high production and intense denitrification", with $\delta^{15} \mathrm{~N}$ values similar to those from our records after $1820 \mathrm{AD}$. The short 'high production' periods punctuated longer, persistent periods with "moderate productivity and denitrification", with $\delta^{15} \mathrm{~N}$ values in the same range as we determined for the LIA. The shift in $\delta^{15} \mathrm{~N}$ of our records is approximately $2 \%$. Though lower than the $\delta^{15} \mathrm{~N}$ change during the last deglaciation in the Eastern Tropical and Extratropical South Pacific records (5\%o; Higginson and Altabet, 2004; De Pol-Holz et al., 2006), the shift towards the end of the LIA and others during the late Holocene are of the same order of magnitude and sign as the $\delta^{15} \mathrm{~N}$ millennial shift at $30^{\circ} \mathrm{S}$ off Chile during the Younger Dryas (De Pol-Holz et al., 2006; Fig. 2). Therefore the modern biogeochemical regime in the ESTP established since ca. 1820 AD is an excursion from the background Holocene ocean climate, probably as significant as millennial-scale events, leading to an expansion of the OMZ throughout the ETSP.

\subsubsection{Reduction-oxidation (redox) conditions in surface sediments}

While higher oxygenation in the water column characterized the LIA period prior to $1820 \mathrm{AD}$, sufficiently dysoxic conditions at the sediment-water interface still permitted the preservation of fine laminations in the deeper Pisco site (Fig. 1), as flux varied between terrigenous and organic sources (Gutiérrez et al., 2006). Fine laminations were not preserved at the Callao site during the LIA, probably due to its shallower water depth that would result in more exposure to bottom oxygenation. However, changes in foraminiferal preservation, as inferred by presence/absence of foraminifera, and changes in the benthic foraminiferal assemblage, support the view of less intensely reducing conditions in the surface sediments at both sites during the LIA and increasingly sulphidic conditions after the LIA.

Dissolution of calcitic foraminiferal tests can occur at lower alkalinity, a condition that is met at the surface when sulphate reduction occurs deeper in the sediments (Froelich et al., 1988). Foraminiferal tests were preserved before $1400 \mathrm{AD}$, disappeared in the sediment accumulated during the LIA, and re-appeared after $1820 \mathrm{AD}$. The lack of foraminifers in the LIA layers is attributed to postdepositional dissolution of the tests due to reduced alkalinity. This interpretation is supported by the reduced sulphate reduction during the LIA inferred from Mo content (Sifeddine et al., 2008), by the finding of tests in the Pisco core just below a slump dated at the LIA (Morales et al., 2006; see also Fig. 3e, n), and by the presence of test linings in core slab thin-sections around the same period. In addition, biological mixing and slower sedimentation rates likely enhanced test dissolution in the Callao core.

Among the benthic foraminiferal species present in the Peruvian margin, Bolivina seminuda is increasingly dominant as conditions become more dysoxic (Resig, 1981). Therefore we use the percent contribution of $B$. seminuda to the benthic foraminiferal assemblage as a proxy of bottom water oxygen and redox conditions at the sediment/water interface (Fig. 3e, n). B. seminuda was present in the records 
before the LIA, comprising between 25 and $75 \%$ of the total abundance. After the $1820 \mathrm{AD}$ shift, it rapidly increased with time at both sites attaining about $90 \%$ dominance at ca. $1950 \mathrm{AD}$, and then exhibited decadal oscillations until the present. The behaviour of $B$. seminuda after the shift resembles the variability of Mo records (Sifeddine et al., 2008). Mo displays a quasi-conservative behaviour in the water column, and it is scavenged when free sulphide and elemental sulphur species are present in the water column, in pore waters, or even in sediment anoxic microniches (Tribovillard et al., 2006, 2008). On the Peruvian margin the highest Mo enrichment occurs in organic-rich sediments within the OMZ and on the shelf (Böning et al., 2004; McManus et al., 2006). The increases of dominance of $B$. seminuda and Mo concentrations at ca. 1820 AD (Fig. 3f, o) are therefore consistent with a rapid upward expansion of the anoxic layer within the surface sediments.

\subsubsection{Preservation of proxies of siliceous and fish pro- ductivity}

Various proxies of primary and tertiary productivity further support an abrupt shift toward higher productivity and reduced oxygenation. Diatoms and amorphous silica exhibited similar patterns throughout the records (Fig. 3h, q), most notably lowest values during the LIA, and an abrupt increase occurred near 1820 AD. Persistently higher primary productivity after $1820 \mathrm{AD}$ may not be apparent in the individual records of diatoms (or amorphous silica) as there is a negative correlation between diatom valves and TOC $\left(r=-0.79^{* *}\right.$, $n=37$; and $r=-0.69^{* *}, n=42$, for Callao and Pisco, respectively). Higher alkalinity due to enhanced sulphate reduction near the sediment interface leads to an increase of dissolution of diatom valves (Froelich et al., 1988). Thus, the increasing sulphidic conditions associated with higher TOC fluxes after the shift, as inferred by Mo and other redox-sensitive records, may have increased the dissolution of biogenic silica, biasing the record of siliceous productivity after $1820 \mathrm{AD}$.

Changes in bottom water oxygen concentration may affect the preservation of fish scales (Salvatteci, 2008). Fish scales have more fissures and altered colorations in the centuries immediately preceding the shift, indicating that greater degradation may be partly responsible for the reduced number of fish scales. Additionally, fish scales show more signs of degradation in the shallower Callao site, located closer to the oxycline, making direct comparisons of fish scale abundance and flux between the two cores difficult. Therefore, following DeVries (1979), we consider fish bones and vertebrae as more reliable indicators of variability in local pelagic fish abundance as they are more resistant to degradation or dissolution than fish scales.

\subsubsection{Variability after the 1820 regime shift}

There are two different patterns in the biogeochemical proxies during and after the 1820 shift. The first one, typified by $\delta^{15} \mathrm{~N}$ and foraminifera preservation, shows a step-like change at ca. $1820 \mathrm{AD}$ to persistent higher oxygen depletion and redox conditions. The second pattern, typified by TOC, fish remain fluxes, percent abundance of $B$. seminuda and Mo fluxes shows a rapid increase after $1820 \mathrm{AD}$ that persisted for a few decades, followed by a return towards pre-shift conditions from ca. 1845 to $1865 \mathrm{AD}$, and then a long-term trend towards higher levels. Cd fluxes exhibit an intermediate behaviour, probably because their records are influenced by sediment redox conditions. However, fluxes of diatom and biogenic silica are actually higher during 1845-1865 AD due to high abundances of Skeletonema costatum, a species which blooms during upwelling relaxation (Alvarez et al., 2005) and which forms aggregates at warmer temperatures (Thornton and Thake, 1998). Thus this bidecadal period likely corresponds to conditions with fewer upwelling events, more frequent intrusions of oceanic waters and more stratification in the coastal fringe, allowing episodic $S$. costatum blooms, but with oxygen and nutrient concentrations in the upwelling source waters at post-shift levels.

\subsection{Climatic driver for the biogeochemical shift}

Seasonal to interannual variability of water column structure, upwelling intensity and productivity in the ETSP are coupled to the strength of the Walker circulation, the expansion/contraction of the South Pacific Subtropical High (SPSH) and the position of the Intertropical Convergence Zone (ITCZ) (Barber and Chávez, 1983; Strub et al., 1998). Generally, changes in Walker circulation, SPSH and ITCZ are correlated during El Niño (EN) events, whereby the coast of Peru is characterized by reduced productivity and an increase in subsurface oxygenation due to a weakening of the equatorial thermocline and Walker circulation (Morales et al., 1999). While coral records from the mid-Equatorial Pacific suggest enhanced ENSO activity during part of the LIA (Cobb et al., 2003), more comprehensive SST reconstructions, multiproxy records and historical information indicate that the expression of EN events, particularly along the Peru coast was less frequent and/or less intense during the LIA (d'Arrigo et al., 2005; Gergis and Fowler, 2006; Ortlieb, 2000) and therefore a higher frequency of EN events is an unlikely explanation of the LIA conditions reported here.

We hypothesize that the centennial-scale shift in the Peruvian upwelling system around $1820 \mathrm{AD}$ was driven by a northward displacement of the ITCZ and the northern rim of the SPSH from their southward condition during the LIA to their modern positions, coupled with an enhancement of the Walker circulation. Comparison of the $\delta^{15} \mathrm{~N}$ records off Peru with Indo-Pacific records of paleotemperature and paleosalinity shows that a relatively abrupt change occurred in 


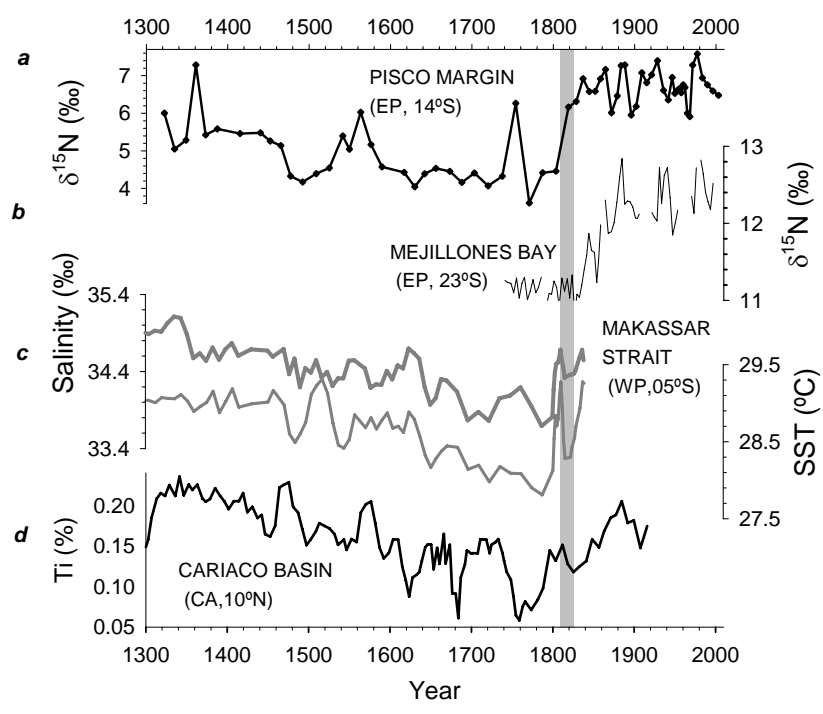

Fig. 4. Comparison of (a) $\delta^{15} \mathrm{~N}$ time-series in Pisco (this study) with paleo records developed in other regions: (b) $\delta^{15} \mathrm{~N}$ time-series in Mejillones Bay, which reflects alongshore winds intensity and influence of ESSW in coastal upwelling off Northern Chile (Vargas et al., 2007), (c) Indo Pacific paleo-temperatures and paleo-salinities based on $\mathrm{Mg}$ : $\mathrm{Ca}$ and $\delta^{18} \mathrm{O} / \delta^{16} \mathrm{O}$ ratios of foraminiferal tests (Newton et al., 2006), (d) percent sedimentary Titanium concentration from the Cariaco Basin taken as an indicator of regional runoff and precipitation (Haug et al., 2001). The gray bar envelopes the shift period, within dating uncertainties.

the Indo-Pacific region at the same time than the biogeochemical shift off Peru (Fig. 4). The large-scale expansion of ESSW and associated increase in productivity imply a basinscale adjustment of the equatorial thermocline/pycnocline tilt and stronger equatorial upwelling (Pennington et al., 2006; Fiedler and Talley, 2006). Taken together, the records also imply enhanced southeast trades, expansion of the cold tongue, and a stronger zonal SST gradient across the Pacific.

Thus, the lower productivity and less oxygen-depleted regime during the LIA was probably maintained by an ITCZ located southward of its modern position and reduced influence of the SPSH along the Peruvian margin. This combination of factors also diminished equatorial upwelling and hence both the zonal and meridional SST gradients in the Eastern Tropical Pacific (Haug et al., 2001; Koutavas and Lynch-Stieglitz, 2004). A northward migration of the ITCZ, as inferred from the Cariaco basin (Fig. 4), might have caused a "tipping point" that established the Walker circulation that is evident in modern times.

There is considerable evidence for a southward displacement of the ITCZ during the LIA, attributed to the cooling of the Northern Hemisphere (Koutavas and Lynch-Stieglitz, 2004). Terrigenous input to the Peruvian continental margin was most probably driven by precipitation and runoff-driven erosion of fine-grained material, followed by river discharge and dispersion by ocean currents (Scheiddeger and Krissek,
1982; Rein et al., 2007). Therefore, the higher lithic fluxes to the Central/Southern Peruvian margin sediments during the LIA are in agreement with continental records that indicate enhanced humidity and monsoonal precipitation in the Western Peruvian Andes (Jomelli et al., 2007; Unkel et al., 2007), when dry climatic conditions characterized the Cariaco Basin (Fig. 4; Haug et al., 2001). Lower salinity in Makassar Strait, a condition that prevailed during the LIA, occurs nowadays during austral summer, associated with higher precipitation and monsoonal winds but not during El Niño events (Gordon et al., 2003; Newton et al., 2006). Figure 5 illustrates how the inferred precipitation patterns during the LIA are consistent with a persistent austral summer-like southward migration of the ITCZ and the associated precipitation belt, rather than a strong zonal (El Niño-like) shift of precipitation eastward.

The southward position of the ITCZ was likely associated with a latitudinal contraction of the SPSH during the LIA, as lower paleotemperatures $\left(U^{K}{ }_{37}\right)$ off Concepcion $\left(36^{\circ} \mathrm{S}\right)$ suggest an increased latitudinal SST gradient across the Eastern Subtropical South Pacific (Vargas et al., 2007). An enhanced latitudinal SST gradient and Hadley circulation also characterized the LIA in the subtropical South Pacific until around 1870 (Hendy et al., 2002).

The $\delta^{15} \mathrm{~N}$ records off Mejillones at $23^{\circ} \mathrm{S}$, Northern Chile, exhibit a delayed and gradual increase of $\delta^{15} \mathrm{~N}$ from 1820 to $1870 \mathrm{AD}$ (Vargas et al., 2007) compared to the step-like change in the Peruvian margin records. It was postulated that $\delta^{15} \mathrm{~N}$ variability off Central Chile during the Holocene is modulated by the formation rate of the Eastern South Pacific Intermediate Waters (ESPIW), which in turn is governed by wind forcing and latitudinal SST gradient at midlatitudes (DePol-Holz et al., 2006, 2007). Currently this water mass ventilates only a thin layer over the thermocline up to Northern Chile (Schneider et al., 2003), but during the Late Glacial Maximum and most of the Holocene it could have been much more developed ventilating the subsurface layer (DePol-Holz et al., 2006). Higher ventilation during the LIA can be expected here if the northward displacement of subtropical fronts is associated to lower SST gradient at mid-latitude. Therefore the slower $\delta^{15} \mathrm{~N}$ rise during the period 1820-1870 AD in Mejillones might be due to persistent ESPIW-driven ventilation, counteracting the increased oxygen depletion originating at low-latitudes. Certainly this hypothesis needs to be examined with more subtropical and mid-latitude late Holocene $\delta^{15} \mathrm{~N}$ and paleotemperature records from the South Eastern Pacific.

The variability in the Peru records between 1820 and $1870 \mathrm{AD}$ can be attributed to changes in the intensity of the SPSH. A continued strengthening of the SPSH and/or coastal winds along the Peruvian margin in the twentieth century may account for the trend towards greater TOC and redox conditions (Sifeddine et al., 2008; see also Fig. 3). This trend contrasts with the variability of water column oxygen and nutrient properties that only show multidecadal-scale fluctuations after 1820, as inferred from $\delta^{15} \mathrm{~N}$ and $\mathrm{Cd}$. This 

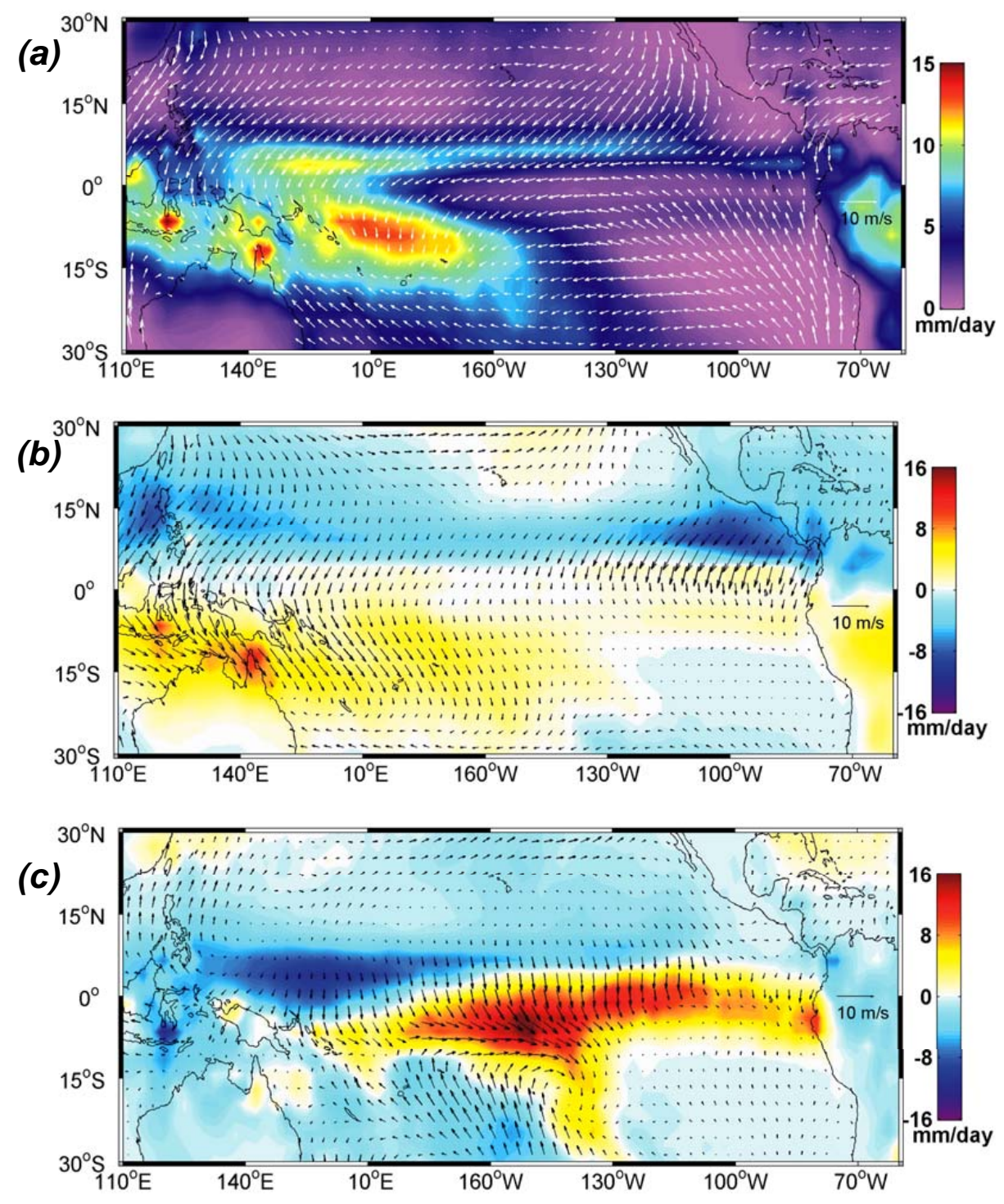

Fig. 5. Austral summer (JFM) versus 1997-1998 El Niño (JFM) precipitation (colors) and wind (arrows) patterns across the Tropical Pacific. Southward displacement of the ITCZ during present day austral summer (leaving dryer conditions in the Cariaco Basin) is coupled with weaker southerly trade winds in the Tropical South Eastern Pacific, as well as with wet conditions both in the Indo Pacific and in the Central Peruvian Andes. (a) Map of JFM climatology of wind (speed and direction) and precipitation; (b) Map of JFM anomalies of wind (speed and direction) and precipitation, relative to the annual cycle; (c) Map of anomalies of surface winds (speed and direction) and precipitation patterns during the 1997-1998 EN (JFM). Winds are from the global monthly Blended Sea Winds available from NCDC (National Climate Data Center) Satellite Data Services. The spatial resolution is 0.25 by 0.25 degrees and extends from July 1987 to October 2007 . Precipitation is from global monthly CMAP (CPC Merged Analysis of Precipitation) data from January 1979 to July 2007 (available from NOAA's Earth System Research Laboratory). The spatial resolution is 2.5 degrees.

decoupling of productivity (TOC) and water column nitrate reduction $\left(\delta^{15} \mathrm{~N}\right)$ differs from the findings of Agnihotri et al. (2008), who suggest that productivity changes and water column nitrate reduction in the late Holocene were tightly coupled at centennial time-scales.

\subsection{Ecosystem responses to the biogeochemical shift}

Diatom analysis suggests that both cool-upwelling and warmer-offshore species were favoured after the $1820 \mathrm{AD}$ shift. While the abrupt increase in diatoms was dominated by the cool-water upwelling diatom assemblage, other groups increased as well (Fig. 6). In particular, oceanic diatoms off Pisco actually make up a greater portion of the total 

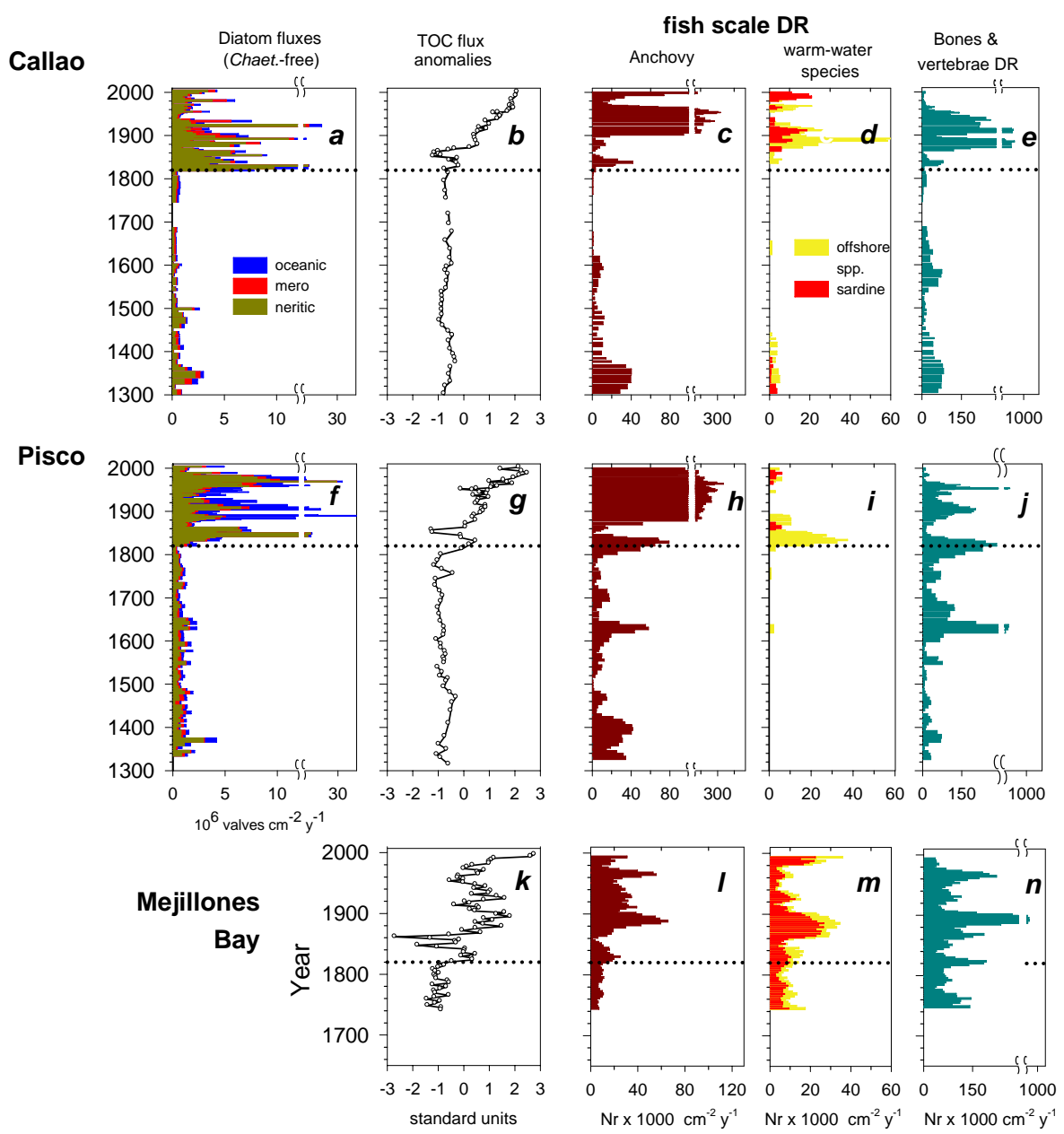

Fig. 6. Pelagic ecosystem proxies off Peru (Callao, a-e; Pisco, $\mathbf{f}-\mathbf{j}$ ) and in Mejillones Bay, Northern Chile (k-n). (a, f) Chaetoceros free diatom accumulation rates (DAR) shown as neritic, meroplanktic and oceanic groupings $\left(10^{6}\right.$ valves $\left.\mathrm{cm}^{-2} \mathrm{y}^{-1}\right)$; $(\mathbf{b}, \mathbf{g}, \mathbf{k}) \mathrm{TOC}$ flux anomalies, to permit comparisons of the variability between sites (standardized units); (c, h, l) 3-term running averages of anchovy scale deposition rates $\left(\mathrm{Nr} \times 1000 \mathrm{~cm}^{-2} \mathrm{y}^{-1}\right) ;(\mathbf{d}, \mathbf{i}, \mathbf{m}) 3$-term running averages of sardine scale deposition rates and offshore pelagic (jack mackerel + mackerel) scale deposition rates $\left(\mathrm{Nr} \times 1000 \mathrm{~cm}^{-2} \mathrm{y}^{-1}\right) ;(\mathbf{e}, \mathbf{j}, \mathbf{n}) 3$-term running averages of deposition rates of bones and vertebrae $\left(\mathrm{Nr} \times 1000 \mathrm{~cm}^{-2} \mathrm{y}^{-1}\right)$.

assemblage during several periods of the high productivity regime.

The response of pelagic fish species is similar, with the increase in productivity after $1820 \mathrm{AD}$ being favourable for both cool-upwelling species as well as species that live in or beyond the upwelling front waters (Fig. 6). The records of fish remains from different locations in Fig. 3 reveal how different species have expanded and contracted both in abundance and population range. It should be noted that diatoms and the conglomerate of pelagic fish shown in Fig. 3 are generally selected in highly productive upwelling ecosystems and that cooler and warmer in this context refers to relative changes within the generally productive condition.

The present day nucleus of the Peruvian anchovy or anchoveta, Engraulis ringens, is from $6^{\circ}$ to $12^{\circ} \mathrm{S}$ and the Callao site lies within this range (Pauly and Tsukayama, 1987).
Since anchoveta is the dominant species in terms of fish scales, we can then assume that vertebrae and other bones in the records are dominated by anchoveta as well. The higher fluxes of fish remains in Callao than in Pisco during the twentieth century is consistent with the modern spatial distribution for this species (Figs. 3i, $r$ and 6).

Fish abundances inferred from bones and vertebrae were dramatically lower prior to $1820 \mathrm{AD}$ off Callao. During warm, less productive periods anchoveta migrate to the Pisco area (Mendo, 1991), which often retains a small upwelling plume even under EN events (Barber and Chávez, 1983). Off Pisco, fluxes of fish bones and vertebrae from 1600 to $1700 \mathrm{AD}$ were as high as during the twentieth century, while in other periods of the LIA they were reduced. Further south, Mejillones Bay $\left(23^{\circ} \mathrm{S}\right)$ is within the distributional area of the present day Northern Chile anchoveta stock (Serra, 1983). 
Fish remains in Mejillones Bay sediments do not show the centennial shift around $1820 \mathrm{AD}$, though fish scales from anchoveta increased slightly around this date (Valdés et al., 2008). The combined records suggest that off Central Peru the main pelagic fish populations were reduced during the LIA, and that the anchoveta population had moved southward.

During the 20th century multidecadal periods of low anchovy abundances are often associated with increases in sardine abundances synchronously off California, Japan and Peru (Schwartzlose et al., 1999; Chavez et al., 2003). Although sardine scales are much thicker and more resistant to degradation than anchoveta scales, no scales were found off Callao or Pisco during the low productivity regime, neither were any from larger offshore species such as jack mackerel (Trachurus murphyi) or horse mackerel (Scomber japonicus peruanus). At Mejillones Bay, scales of sardine and offshore species were present throughout the record with no signs of degradation, but as with bones and vertebrae, fluxes were not higher prior to 1820 . The combined evidence from the three different sites indicates that sardines did not expand during the centennial-scale regime of low productivity. This suggests that the decrease in productivity during LIA was of such magnitude and duration to limit growth of fish populations that in the modern era seem to be adapted to periods of lower productivity.

Within the highly productive regime, a centennial-scale northward expansion of anchoveta is coupled with two multidecadal periods of expansion of sardines (Fig. 6). The former period corresponds to low anchoveta scale fluxes and low fluxes of bones and vertebrae during 1845-1865 AD, which also shows that reduced fluxes of fish debris is not necessarily an artefact of degradation. The latter period corresponds to the multi-decadal "sardine regime" observed in the twentieth century (Chavez et al., 2003). Note that the flux of bones and vertebrae is diminished since the development of the fishery in the 1960s, likely ending up as fish meal rather than passing through the guts of predators and being transported to the sediments.

\subsection{Implications for climate and ecosystem changes}

The reduced Walker circulation during the LIA was probably maintained by a southern displacement of the ITCZ associated with global cooling, in sharp contrast to present-day weakening of the Walker circulation associated with warming across the globe during El Niño periods. Furthermore, the current EN teleconnection that results in precipitation anomalies in Central Chile and Northwestern Peru was absent prior to ca. $1817 \mathrm{AD}$ (Ortlieb, 2000, 2004), likely due to changes in tropical atmospheric circulation at this time. The implication is that we cannot use present-day conditions as predictors of the future and the coupling of important processes (like the ITCZ and Walker circulation) may differ in the future under different climate scenarios.
The abruptness of the regime shift reported here reveals the potential for rapid reorganization in the modern tropical Pacific climate, circulation, ocean biogeochemical cycles and marine productivity. The large and rapid changes in productivity and biogeochemical cycles in the ETSP are of the same magnitude as the gradual centennial to millennial changes during the Holocene. Current global warming favours the expansion of the tropical oxygen minimum areas in the global ocean (Stramma et al., 2008). However, parallel increase of open-ocean stratification, weakening of tropical circulation and trade winds system (Vecchi et al., 2006), and enhancement of coastal upwelling (Bakun, 1990; Bakun and Weeks, 2008) may introduce new instabilities in the present-day biogeochemical regime that started with the end of the LIA.

On the other hand, the ecosystem response after the end of the LIA involved an overall increase of the major groups of diatom and pelagic fish, in contrast to decreased ecosystem productivity in the Eastern Pacific during El Niño and El Viejo (Barber and Chávez, 1983; Chavez et al., 2003). This paradox suggests that the processes at work during recent multidecadal variations may be substantially different from centennial- to millenial-scale changes. Furthermore, without the centennial, climate-driven, increase in bottom-up productivity of the upwelling system the intense anchoveta exploitation during the past decades would not have been possible. Given that looming climate changes may easily exceed variations observed in the twentieth century, major and non-linear regime shifts in the ecosystems that depart from twentieth century paradigms should be expected. Mechanistic understanding is needed to predict future scenarios and to develop adaptive policies.

\section{Conclusions}

Reduced productivity along with greater oxygenation in the water column characterized the ESTP biogeochemical regime during the LIA, from the fifteenth to the early nineteenth century. This regime was likely maintained by a mean southward displacement of the ITCZ relative to its modern range and an associated weakening of the SPSH.

A rapid expansion of nutrient-rich, oxygen depleted waters occurred in the ETSP around $1820 \mathrm{AD}$, probably driven by the northward shift of the ITCZ, the expansion of the SPSH and a spin-up of tropical circulation that has persisted (and perhaps strengthened) through modern time. The magnitude of the shift in biogeochemical cycling and particularly in the regional marine nitrogen budgets appears similar to other centennial excursions from the background Holocene climate and to millennial-scale change during the Younger Dryas in the Eastern South Pacific. The impact on the ecosystem was an overall increase in primary and fish productivity that has continued during the twentieth century. 
Acknowledgements. We acknowledge support from the Instituto del Mar del Peru (IMARPE) PALEOMAP research program, the IRD PALÉOTROPIQUE research unit (UR 055), the PALEOPECES project (IMARPE-IRD), the IAI small grant project SGP 211-222 (P. I. D. G.), the Humboldt Current System program (ATI-IRD), the JEAI Mixpaleo project (IMARPE/INGEMMET), the AIEA Coordinated Research Project "Nuclear and isotopic studies of the El Niño phenomenon in the ocean" (research contract $\mathrm{N}^{\circ}$ 12789), NASA and the David and Lucile Packard Foundation. Research contributions of D. F. came from the NSF International Research Fellowship Program (IRFP award OISE-0502387). We particularly acknowledge the crew of the RV José Olaya Balandra and other scientific participants in the box-coring survey. We also acknowledge Ms. Dorota Kolber (MBARI) for her valuable help with Figs. 1 and 4.

Edited by: S. W. A. Naqvi

\section{References}

Altabet, M. A., Pilskaln, C., Thunell, R., Pride, C., Sigman, D., Chavez, F., and Francois, R.: Nitrogen isotope biogeochemistry of sinking particles of the eastern North Pacific, Deep Sea Res. I, 46, 655-679, 1999.

Agnihotri, R., Altabet, M. A., Herbert, T. D., and Tierney, J. E.: Subdecadally resolved paleoceanography of the Peru margin during the last two millennia, Geochem. Geophys. Geosys., 9, Q05013, doi:10.1029/2007GC001744, 2008.

Alvarez-Salgado, X. A., Nieto-Cid, M., Piedracoba, S., Crespo, B. G., Gagol, J., Brea, S., Teixera, G., Garrido, J. L., Rosón, G., Castro, C. G., and Gilcoto, M.: Origin and fate of a bloom of Skeletonema costatum during a winter upwelling/downwelling sequence in the Ría de Vigo (NW Spain), J. Mar. Res., 63, 11271149, 2005.

Bakun, A.: Global climate change and intensification of coastal ocean upwelling, Science, 247, 198-201, 1990.

Bakun, A. and Weeks, S. J.: The marine ecosystem off Peru: what are the secrets of its fishery productivity and what might its future hold?, Prog. Oceanogr., 79, 290-299, 2008.

Barber, R. T. and Chavez, F. P.: Biological consequences of El Niño, Science, 222, 1203-1210, 1983.

Batterbee, R. W.: Diatom Analysis, in: Handbook of Holocene Palaeoecology and Palaeohydrology, edited by: Berglund, B. E., John Wiley and Sons, New York, USA, 527-570, 1986.

Bertaux, J., Frohlich, F., and Ildefonse, Ph.: Multicomponent analysis of FTIR spectra: quantification of amorphous silica and crystallized mineral phases in synthetic and natural sediments, J. Sediment. Res., 68, 440-447, 1998.

Böning, Ph., Brumsack, H. J., Böttcher, M. E., Schnetger, B., Kriete, C., Kallmeyer, J., and Borcher, S. L.: Geochemistry of Peruvian near-surface sediments, Geochim. Cosmochim. Ac., 68, 4429-4451, 2004.

Broecker, W.: Was a change in thermohaline circulation responsible for the Little Ice Age?, Proc. Natl. Acad. Sci., 97, 1339-1342, 2000.

Boussafir, M., Gelin, F., Lallier-Vergès, E., Derenne, S., Bertrand, P., and Largeau, C.: Electron microscopy and pyrolysis of kerogens from Kimmeridge Clay Formation, UK: source organisms, preservation processes and origin of microcycles,. Geochim. Cosmochim. Ac., 59, 3731-3747, 1995.

Chávez, F., Ryan, J., Lluch-Cota, S., and Niquen, M.: From anchovies to sardines and back; climate, fish, ocean productivity, and atmospheric carbon dioxide, Science, 299, 217-221, 2003.

Cho, Y., Lee, C., and Choi, M.: Geochemistry of surface sediments off the southern and western coast of Korea, Mar. Geol., 159, 111-129, 1999.

Cobb, K., Charles, C., Cheng, H., and Edwards, R.: El Niño/Southern Oscillation and tropical Pacific climate during the last millennium, Nature, 424, 271- 276, 2003.

Cronin, T., Dwyer, G., Kamiya, T., Schwede, S., and Willard, D.: Medieval Warm Period, Little Ice Age and 20th century temperature variability from Chesapeake Bay, Global Planet. Change, 36, 17-29, 2003.

D’Arrigo, R., Cook, E., Wilson, R., Allan, R., and Mann, M.: On the variability of ENSO over the past six centuries, Geophys. Res. Lett., 32(1-4), L03711, doi:10.1029/2004GL022055, 2005.

Dean, W., Zheng, Y., Ortiz, J. D., and Van Geen, L.: Sediment $\mathrm{Cd}$ and Mo accumulation in the oxygen-minimum zone off western Baja California linked to global climate over the past $52 \mathrm{kyr}$, Paleoceanography, 21, PA4209, doi:10.1029/2005PA001239, 2006.

De Pol-Holz, R., Ulloa, O., Dezileau, L., Kaiser, J., Lamy, F., and Hebbeln, D.: Melting of the Patagonian Ice Sheet and deglacial perturbations of the nitrogen cycle in the eastern South Pacific, Geophys. Res. Lett., 33, L04704, doi:10.1029/2005GL024477, 2006.

De Pol-Holz, R., Ulloa, O., Lamy, F., Dezileau, L., Sabatier, P., and Hebbeln, D.: Late Quaternary variability of sedimentary nitrogen isotopes in the eastern South Pacific Ocean, Paleoceanography, 22, PA2207, doi:10.1029/2006PA001308, 2007.

DeVries, T.: Nekton remains, diatoms, and Holocene upwelling off Peru, Master Sci. Thesis, Oregon State University, USA, 85 pp., 1979.

Fiedler, P. C. and Talley, L. D.: Hydrography of the eastern tropical Pacific: a review, Progr. Oceanogr., 69, 143-180, 2006.

Field, D. B., Baumgartner, T. R., Charles, C. D., Ferreira-Bartrina, V., and Ohman, M. D.: Planktonic foraminifera of the California Current reflect 20th-century warming, Science, 311, 63-66, 2006.

Froelich, P. N., Arthur, M. A, Burnett, W. C., Deakin, M., Hensley, V., Jahnke, R. Kaul, L., Kim, K.-H., Roe, K., Soutar, A., and Vathakanon, C.: Early diagenesis of organic matter in Peru continental margin sediments: Phosphorite Precipitation in: The Origin of Marine Phosphorite. The Results of the R. V. Robert D. Conrad Cruise 23-06 to the Peru Shelf, edited by: Burnett, W. C. and P. N., Froelich, Mar. Geol. (special issue), 80, 309-343, 1988.

Gergis, J. L. and Fowler, A. M.: How unusual was late 20th century El Niño-Southern oscillation (ENSO)? Assessing evidence from tree-ring, coral, ice-core and documentary palaeoarchives, AD 1525-2002, Adv. Geosci., 6, 173-179, 2006, http://www.adv-geosci.net/6/173/2006/.

Graham, N., Hughes, M., Ammann, C., Cobb, K., Hoerling, M., Kennett, D., Kennett, J., Rein, B., Stott, L., Wigand, P., and Xu, T. Y.: Tropical Pacific - mid-latitude teleconnections in medieval times, Climatic Change, 83, 241-285, 2007.

Gordon, A., Susanto, R., and Vranes, K.: Cool Indonesian through- 
flow as a consequence of restricted surface layer flow, Nature, 425, 824-828, 2003.

Gutiérrez, D., Sifeddine, A., Reyss, J. L., Vargas, G., Velazco, F., Salvatteci, R., Ferreira, V., Ortlieb, L., Field, D., Baumgartner, T., Boussafir, M., Boucher, H., Valdés, J., Marinovic, L., Soler, P., and Tapia, P.: Anoxic sediments off Central Peru record interannual to multidecadal changes of climate and upwelling ecosystem during the last two centuries, Adv. Geosci., 6, 119-125, 2006, http://www.adv-geosci.net/6/119/2006/.

Haug, G. H., Hughen, K. A., Sigman, D. M., Peterson, L. C., and Röhl, U.: Southward migration of the Intertropical Convergence Zone through the Holocene, Science, 293, 1304-1308, 2001.

Hendy, E., Gagan, M., Alibert, Ch., McCulloch, M., Lough, J., and Isdale, P.: Abrupt decrease in tropical Pacific sea surface salinity at the end of the Little Ice Age, Science, 295, 1511-1514, 2002.

Higginson, M. and Altabet, M.: Initial test of the silicic acid leakage hypothesis using sedimentary biomarkers, Geophys. Res. Lett., 31, L18303, doi:10.1029/2004GL020511, 2004.

Jomelli, V., Grancher, D., Brunstein, D., and Solomina, O.: Recalibration of the yellow Rhizocarpon growth curve in the Cordillera Blanca (Peru) and implications for LIA chronology, Geomorphology, 93, 201-212, 2008.

Koide, M. and Goldberg, E.: Transuranic nuclides in two coastal marine sediments off Peru, Earth Planet. Sci. Lett., 57, 263-277, 1982.

Koutavas, A. and Lynch-Stieglitz, J.: Variability of the marine ITCZ over the eastern Pacific during the past 30000 years: Regional perspective and global context, in: The Hadley Circulation: Present, Past and Future, edited by: Bradley, R. S. and Diaz, H. F., Kluwer Academic Publishers, 347-369, 2004.

Krissek, L. A., Scheidegger, K. F., and Kulm, L. D.: Surface sediments off the Peru-Chile continental margin and the Nazca plate, Bull. Geol. Soc. Am., 91, 321-331, 1980.

Laws, E. A., Falkowski, P. G., Smith, W. O., Ducklow, H., and McCarthy, J. J.: Temperature effects on export production in the open ocean, Global Biogeochem. Cy., 14, 1231-1246, 2000.

Mann, M., Cane, M., Zebiak, S., and Clement, A.: Volcanic and Solar Forcing of the Tropical Pacific over the Past 1000 Years, J. Climate, 18, 447-456, 2005.

Mantua, N.: Methods for detecting regime shifts in large marine ecosystems: A review with approaches applied to North Pacific data, Progr. Oceanogr., 60, 165-182, 2004.

Martinez, P., Lamy, F., Robinson, R., Pichevin, L., and Billy, I.: Atypical $\delta^{15} \mathrm{~N}$ variations at the southern boundary of the East Pacific oxygen minimum zone over the last $50 \mathrm{ka}$, Quaternary Sci. Rev., 25, 3017-3028, 2006.

McManus, J., Berelson, W., Severmann, S., Poulson, R., Hammond, D., Klinkhammer, G., and Holm, C.: Molybdenum and uranium geochemistry in continental margin sediments: paleoproxy potential, Geochim. Cosmochim. Ac., 70, 4643-4662, 2006.

Mendo, J.: Stock identification of Peruvian anchoveta (Engraulis ringens): morphometric; tagging/recapture, electrophoretic and ecological studies, Dr. rer. nat. thesis, University of Bremen, Germany, 1992.

Meyers, P. A.: Organic geochemical proxies of paleoceanographic, paleolimnologic, and paleoclimatic processes, Org. Geochem., 27, 213-250, 1997.

Morales, C. E., Hormazabal, S. E., and Blanco, J. L.: Interannual variability in the mesoscale distribution of the depth of the upper boundary of the oxygen minimum layer off northern Chile (18$24^{\circ} \mathrm{S}$ ): Implications for the pelagic system and biogeochemical cycling, J. Mar. Res., 57, 909-932, 1999.

Morales, M. C., Field, D., Pastor, S. M., Gutiérrez, D., Sifeddine, A., Ortlieb, L., Ferreira, V., Salvatteci, R., and Velazco, F.: Variations in foraminifera over the last 460 years from laminated sediments off the coast of Peru, Bol. Soc Perú, 101, 5-18, 2006.

Newton, A., Thunell, R., and Stott, L.: Climate and hydrographic variability in the Indo-Pacific Warm Pool during the last millennium, Geophys. Res. Lett., 33, L19710. doi:10.1029/2006GL027234, 2006.

Ortlieb, L.: The documentary historical record of El Niño events in Peru: An update of the Quinn record (sixteenth through nineteenth centuries), in: El Niño and the Southern Oscillation: Variability, Global and Regional Impacts, edited by: Diaz, H. and Markgraf, V., Cambridge University Press, USA, 207-295, 2000.

Ortlieb, L.: Historical chronology of ENSO and the Nile flood record, in: Past Climate Variability through Europe and Africa, edited by: Batterbee R. W., Gasse F., and Stickley, C. E., Springer, Dordrecht, The Netherlands, 257-278, 2004.

Pauly, D. and Tsukayama, I.: On the implementation of management oriented fishery research: the case of the peruvian anchoveta, in: The Peruvian ancboveta and its upwelling ecosystem: three decades of changes, edited by: Pauly, D. and Tsukayama, I., ICLARM Studies and Reviews, 15, 1-13, 1987.

Peterson, L. and Haug, G.: Variability in the mean latitude of the Atlantic Intertropical Convergence Zone as recorded by riverine input of sediments to the Cariaco Basin (Venezuela), Palaeogeogr. Palaeocl., 234, 97-113, 2006.

Pennington, J. T., Mahoney, K. L., Kuwahara, V. S., Kolber, D., Calienes, R., and Chavez, F. P.: Primary production in the eastern tropical Pacific: A review, Prog. Oceanogr., 69, 285-317, 2006.

Pichevin, L., Bertrand, P., Boussafir, M., and Disnar, J.-R.: Organic matter accumulation and preservation controls in a deep sea modern environment: an example from Namibia slope sediments, Org. Geochem., 35, 543-559, 2004.

Rein, B., Lückge, A., and Sirocko, F.: A major Holocene ENSO anomaly during the Medieval period, Geophys. Res. Lett., 31, L17211. doi:10.1029/2004GL020161, 2004.

Rein, B.: How do the 1982/83 and 1997/98 El Niños rank in a geological record from Peru?, Quatern. Int., 161(1), 56-66, doi:10.1016/j.quaint.2006.10.023, 2007.

Reinhardt, L., Kudrass, H.-R., Lückge, A., Wiedicke, M., Wunderlich, J., and Wendt, G.: High-resolution sediment echosounding off Peru: Late Quaternary depositional sequences and sedimentary structures of a current-dominated shelf, Mar. Geophys. Res., 23, 335-351, 2002.

Resig J.: Biogeography of benthic Foraminifera of the northern Nazca Plate and adjacent continental margin, Geol. Soc. Am., 154, 619-665, 1981.

Salvatteci, R.: Flujos y preservación de escamas y restos óseos de peces en la zona de mínimo de oxígeno frente a Pisco, Perú en los últimos 400 años, M. S. thesis, Centro de Investigación y de Educación Superior de Ensenada, México, 89 pp., 2008.

Scheidegger, K. F. and Krissek, L. A.: Dispersal and deposition of eolian and fluvial sediments off Peru and northern Chile, Bull. Geol. Soc. Am., 93, 150-162, 1982.

Schmittner, A., Galbraith, E., Hostetler, S., Pedersen, T., and Zhang, 
$\mathrm{R}$ : Large fluctuations of dissolved oxygen in the Indian and Pacific Oceans during Dansgaard-Oeschger oscillations caused by variations in North Atlantic deep water subduction, Paleoceanography, 22, PA3207, doi:10.1029/2006PA001384, 2007.

Schneider, W., Fuenzalida, R. , Rodrıguez-Rubio, E., GarcésVargas, J., and Bravo, L.: Characteristics and formation of eastern South Pacific intermediate water, Geophys. Res. Lett., 30, 1581, doi:10.1029/2003GL017086, 2003.

Schwartzlose, R. Alheit, J., Bakun, A., Baumgartner, T., Cloete, R., Crawford, R., Fletcher, W., Green-Ruiz, Y., Hagen, E., Kawasaki, T., Lluch-Belda, D., Lluch-Cota, S., Maccall, A., Matsuura, Y., Nevárez, M., Parrish, R., Roy, C., Serra, R., Shust, K., Ward, M., and Zuzunaga, J.: Worldwide Large-scale Fluctuations of Sardine and Anchovy Populations, S. Afr. J. Marine Sci., 21, 289-347, 1999.

Serra, R.: Changes in the abundance of pelagic resources along the chilean coast, FAO Fish. Rep., 291(2), 255-284, 1983.

Sifeddine, A., Gutierrez, D., Ortlieb, L., Boucher, H., Velazco, F., Field, D., Vargas, G., Boussafir, M., Salvatteci, R., Ferreira, V., García, M., Valdes, J., Caquineau, S., Mandeng Yogo, M., Cetin, F., Solis, J., Soler, P., and Baumgartner, T.: Laminated sediments from the central Peruvian continental slope: A 500 year record of upwelling system productivity, terrestrial runoff and redox conditions, Prog. Oceanogr., 79, 190-197, 2008.

Skilbeck, C. G. and Fink, D.: Data report: Radiocarbon dating and sedimentation rates for Holocene - upper Pleistocene sediments, eastern equatorial Pacific and Peru continental margin, in: In: Proceedings of the Ocean Drilling Program, Scientific Results, Vol. 201, edited by: Jørgensen, B. B., D’Hondt, S. L., and Miller, D. J., 1-15, online available at: http://www-odp.tamu. edu/publications/, 2006.

Stramma, L., Johnson, G., Sprintall, J., and Mohrholz, V.: Expanding Oxygen-Minimum Zones in the Tropical Oceans, Science, 320, 655-658, 2008.

Strub, P., Mesias, J., Montecinos, V., Rutllant, J., and Salinas, S.: Coastal ocean circulation off western South America, in: The Sea, Vol. 11, edited by: Robinson, A. and Brink, K., John Wiley Sons, New York, USA, 273-313, 1998.

Takesue, R., Van Geen, A., Carriquiry, L., Ortiz, E., GodinezOrta, L., Granados, I., Saldívar, M., Ortlieb, L., Escribano, R., Guzmán, N., Castilla, J., Varas, M., Salamanca, M., and Figueroa, C.: Influence of coastal upwelling and El NiñoSouthern Oscillation on nearshore water along Baja California and Chile: shore-based monitoring during 1997-2000, J. Geophys. Res., 109, 1-14, 2004.
Taylor, R. E and Berger, R.: Radiocarbon content of marine shells from the Pacific coasts of Central and South America, Science, 158, 1180-1182, 1967.

Thornton, D. and Thake, B.: Effect of temperature on the aggregation of Skeletonema costatum (Bacillariophyceae) and the implication for carbon flux in coastal waters, Mar. Ecol. Prog. Ser., 174, 223-231, 1998.

Tribovillard, N., Algeo, Th., Lyons, T., and Riboulleau, A.: Trace metals as paleoredox and paleoproductivity proxies: An update, Chem. Geol., 232, 12-32, 2006.

Tribovillard, N., Lyons T. W., Riboulleau, A., and BoutRoumazeilles, V.: A possible capture of molybdenum during early diagenesis of dysoxic sediments, Bull. Soc. Géol., France, 179, 1-16, 2008.

Unkel, I., Kadereit, A., Bertil, M., Bernhard, E., Kromer, B., Wagner, G., and, Wacker, L.: Dating methods and geomorphic evidence of palaeoenvironmental changes at the eastern margin of the the South Peruvian coastal desert $\left(14^{\circ} 30^{\prime} \mathrm{S}\right)$ before and during the Little Ice Age, Quatern. Int., 175, 3-28, 2007.

Valdés, J., Sifeddine, A., Lallier-Verges, E., and Ortlieb, L.: Petrographic and geochemical study of organic matter in surficial laminated sediments from an upwelling system (Mejillones del Sur Bay, Northern Chile), Org. Geochem., 35, 881-894, 2004.

Valdés, J., Román, D., Dávila, P., Ortlieb, L., and Guíñez, M.: Variabilidad estacional de cadmio en un sistema de surgencia costera del norte de Chile (Bahía Mejillones del Sur, 23 $\mathrm{S}$ ), Rev. Chil. Hist. Nat., 79, 517-535, 2006.

Valdés, J., Ortlieb, L., Gutiérrez, D., Marinovic, L., Vargas, G., and Sifeddine, A.: A 250 years - sedimentary record of Sardine and Anchovy scale deposition in Mejillones Bay, $23^{\circ} \mathrm{S}$, Northern Chile, Prog. Oceanogr., 198-207, 2008.

Vargas, G., Pantoja, S., Rutllant, J., Lange, C., and Ortlieb, L.: Enhancement of coastal upwelling and interdecadal ENSO-like variability in the Peru-Chile Current since late 19th century, Geophys. Res. Lett., 34, L13607, doi:10.1029/2006GL028812, 2007.

Vecchi, G. A., Soden, B. J., Wittenberg, A. T., Held, I. M., Leetmaa, A., and Harrison, M. J.: Weakening of tropical Pacific atmospheric circulation due to anthropogenic forcing, Nature, 441, 73-76, 2006. 